\title{
PAX8 and peroxisome proliferator-activated receptor gamma 1 gene expression status in benign and malignant thyroid tissues
}

Ludovic Lacroix ${ }^{1}$, Caterina Mian ${ }^{1,2}$, Thierry Barrier ${ }^{1}$, Monique Talbot ${ }^{3}$, Bernard Caillou ${ }^{3}$, Martin Schlumberger ${ }^{2}$ and Jean-Michel Bidart ${ }^{1}$

CNRS UMR 8125-Commissariat à l'Energie Atomique, LRC29V, and Departments of ${ }^{1}$ Clinical Biology, ${ }^{2}$ Nuclear Medicine and ${ }^{3}$ Pathology, Institut Gustave-Roussy, 94805 Villejuif Cedex, France

(Correspondence should be addressed to J-M Bidart, Institut Gustave-Roussy, 39, rue Camille Desmoulins, 94805 Villejuif, France; Email: bidart@igr.fr.)

\begin{abstract}
Objective: Genetic alterations involving the thyroid transcription factor PAX8 and the peroxisome proliferator-activated receptor gamma 1 (PPAR $\gamma 1$ ) genes have been described in thyroid neoplasms. We investigated in a series of thyroid samples, including 14 normal, 13 hyperfunctioning tissues, 26 follicular adenomas, 21 follicular and 41 papillary carcinomas, both the frequency of the PAX8-PPAR $\gamma 1$ rearrangement and the expression of the PAX8 and PPAR $\gamma$ transcripts.

Methods: Using RT-PCR followed by sequencing PCR products, PAX8-PPAR $\gamma 1$ translocation was not detected in benign tissues nor in papillary carcinomas and was detected in 4 (19\%) of 21 follicular carcinomas and in one (4\%) of 26 follicular adenomas.

Results: Specific real-time quantitative RT-PCR (Q RT-PCR) methods detected high levels of PPAR $\gamma$ transcripts in follicular carcinomas presenting the rearrangement. Interestingly, the level of PPAR $\gamma$ transcripts was significantly decreased in papillary carcinomas in comparison with those found in benign adenomas and follicular carcinomas. Finally, PAX8 gene expression was decreased in both papillary and follicular thyroid carcinomas, and in these tumors to the same extent in the presence or absence of the rearrangement. These alterations in both PPAR $\gamma$ and PAX8 gene expression may explain the poorly differentiated histotype of follicular carcinomas harboring the translocation. Immunohistochemistry showed that nuclear PPAR $\gamma$ staining was weak in normal tissues, adenomas, papillary carcinomas and in some follicular carcinomas, and strong in the follicular carcinomas positive for the PAX8-PPAR $\gamma 1$ translocation, but also in some follicular tumors in which no translocation could be evidenced.

Conclusion: These observations confirm that the PAX8-PPAR $\gamma 1$ translocation characterizes a subset of thyroid follicular carcinomas but is not a specific marker of carcinoma and that its frequency is lower than that initially reported. Finally, immunohistochemistry is not a reliable method for the specific detection of the translocation, that can be specifically evidenced by Q RT-PCR.
\end{abstract}

\section{European Journal of Endocrinology 151 367-374}

\section{Introduction}

Follicular cell-derived thyroid tumors include benign adenomas, papillary and follicular carcinomas, two entities considered as differentiated carcinomas, and anaplastic carcinomas (1). Genetic abnormalities found in these tumors have been largely substantiated (2), and chromosomal rearrangements are typical features of differentiated thyroid carcinomas (3). The RET/PTC oncogene, generated by the fusion of the tyrosine-kinase domain of the RET gene and the $5^{\prime}$ domain of various genes was detected in papillary carcinomas and with a high frequency in radiation-associated carcinomas (4); NTRK1 rearrangement was also found in papillary carcinomas $(2,3)$. Chromosomal imbalances are frequent in follicular neoplasms, with gains at chromosomes 7 and 5 and deletions at $3 p(5,6)$. In these tumors, the $\mathrm{t}(2 ; 3)(\mathrm{q} 13 ; \mathrm{p} 25)$ rearrangement results in the fusion of the DNA binding domains of the thyroid transcription factor PAX8 to DNA binding, ligand binding, RXR dimerization and transactivation domains of the peroxisome proliferator-activated receptor gamma 1 (PPAR $\gamma 1)(7)$.

PPAR $\gamma$ belongs to the nuclear hormone receptor superfamily and plays a critical role in the differentiation of adipocytes and in the regulation of fat metabolism (8, 9). Although their precise mechanism of action remains unknown, the anti-proliferative effects of PPAR $\gamma$ agonists have been demonstrated in tumor cell lines, including those established from thyroid carcinomas (10-13). Furthermore, changes in expression, mutations and polymorphism within the PPAR $\gamma$ gene have been depicted in various malignancies $(10,14-16)$. PAX8, a member of the paired domain-containing gene family, plays a key role in thyroid cell differentiation (17). In the adult thyroid gland, 
PAX8 regulates the expression of major thyroid genes and its expression is more profoundly decreased in carcinomas than in adenomas (18).

The PAX8-PPAR $\gamma 1$ fusion oncogene appears to act through a dominant negative effect on the transcriptional activity of the wild-type PPAR $\gamma 1$. The frequency of the rearrangement in follicular carcinomas ranges from 10 and $63 \%$ among series, depending on the number of tumors tested and the method used $(7,19-27)$. The PAX8-PPAR $\gamma 1$ rearrangement was also detected in some follicular adenomas but these could be early minimally invasive follicular carcinomas (19-21). This observation suggests that the PAX8PPAR $y 1$ rearrangement is not a reliable marker of malignancy and is not sufficient per se for carcinogenesis $(20,21)$. In contrast, the rearrangement was not found in Hürthle cell tumors, papillary carcinomas and in hyperplastic thyroid tissues (7, 19, 20, 22, 25).

In the present report, we analyzed a large series of benign hyper- and hypofunctioning thyroid tissues, and of papillary and follicular carcinomas for the presence of the PAX8-PPAR $\gamma 1$ fusion oncogene by RT-PCR followed by sequencing. We then developed a real-time quantitative RT-PCR (Q RT-PCR) to quantify the expression level of PAX8 and PPAR $\gamma$ genes, and an immunohistochemical method to evaluate PPAR $\gamma$ protein expression. Polymorphisms at codons 12 and 449 that have been reported to be associated with some malignant tumors have also been analyzed in these samples.

\section{Materials and methods}

\section{Tissue samples}

Thyroid tissue samples were selected after histological analysis and classified according to World Health Organization recommendations (1). They included hyperfunctioning tissues, including Graves' thyroid tissues and toxic adenomas $(n=13)$, benign hypofunctioning follicular adenomas $(n=26)$, and papillary $(n=41)$ and follicular $(n=21)$ thyroid carcinomas. Among follicular carcinomas, 15 were poorly differentiated (either microfollicular, insular or Hürthle cell carcinoma) including 14 widely invasive and one minimally invasive. The other six were well differentiated macrofollicular carcinomas, including five minimally invasive and one widely invasive. The clinical features of follicular thyroid carcinoma patients are presented in Table 1. Briefly, follicular carcinomas occurred in 10 males and 11 females with a mean age of 50 years. According to the TNM classification (Table 1), seven tumors were classified as stage I, four as stage II, one as stage III, and nine as stage IV (28). Finally, normal thyroid tissues $(n=14)$ obtained from patients with a unifocal papillary carcinoma, were used as calibrators. All specimens were frozen at $-80^{\circ} \mathrm{C}$ in isopentane and stored in liquid nitrogen before RNA extraction. All patients, except those with Graves' disease or toxic adenoma were euthyroid at the time of surgery as shown by a normal serum thyrotropin (TSH) level. Informed consent was obtained from all patients.

\section{RT-PCR for detection of PAX8-PPAR $\gamma 1$ translocation}

Total RNA was isolated from tissue samples using a DNA/RNA Extraction Midi Kit according to the manufacturer's instructions (Qiagen, Hilden, Germany). The quality of RNA was controlled by conventional gel electrophoresis, stained with ethidium bromide; $28 \mathrm{~S}$ and $18 \mathrm{~S}$ bands were visualized under UV illumination. The quantification yield was assessed by spectrophotometry. RNA $(1 \mu \mathrm{g})$ was reverse transcribed with Moloney murine leukemia virus reverse transcriptase at $42{ }^{\circ} \mathrm{C}$ for $45 \mathrm{~min}$ in a $20-\mu \mathrm{l}$ volume reaction, in the presence of random primers. Two microliters reversed-transcribed mixture (cDNA $0.1 \mu \mathrm{g}$ ) were amplified by PCR for detection of PAX8-PPAR $\gamma 1$ translocation. PCR reaction was assessed with forward primer for exon 7 of PAX8 (5'-GCAACCTCTCGACTCACCAG-3') and reverse primer for exon 1 of PPAR $\gamma 1$ (5'-CATTACGGAGAGATCCACGG-3'), as previously described (7). PCR products of the four positive samples were separated using 2\% agarose gel electrophoresis (SeaPlaque GTG Agarose, FMC Bioproduct, Rockland, ME, USA). Each band was purified with QIAquick Gel Extraction Kit (Qiagen) according to the manufacturer's instructions. These purified products were directly sequenced using Big Dye Terminator Cycle Sequencing Kit (Applied Biosystems, Foster City, CA, USA). All samples were also tested with the primers described by Nikiforova et al. (23).

\section{Determination of mRNA level of PPAR $\gamma$ and PAX8 using real-time quantitative PCR}

Determination of the PPAR $\gamma$ and PAX8 gene expression was performed in all thyroid tissue samples. Oligonucleotide primers and Taqman probes specific for PPAR $\gamma$ and PAX8a were designed to be intron spanning using the computer program Primer Express (Applied Biosystems) and GenBank databases. Their sequences are presented in Table 2. For PPAR $\gamma$, the primers and the probe were located in exons 5-6. The analysis did not allow us to distinguish between fusion oncogene transcripts and wild-type PPAR $\gamma$ transcripts.

Real-time quantitative PCR was set up in 96-sample tubes/assay using a cDNA equivalent of $20 \mathrm{ng} / \mathrm{total}$ RNA per tube as previously described (29). To normalize for the differences in the amount of total RNA added to the reaction, amplification of $18 \mathrm{~S}$ ribosomal RNA was performed as an endogenous control. A pool of 5 normal thyroid tissues was used as a calibrator ( $1 \times$ sample) for determining the relative expression of PAX8 and PPARy genes in tissues as previously 
Table 1 Clinical, pathological and molecular features of patients with a follicular thyroid carcinoma

\begin{tabular}{|c|c|c|c|c|c|c|c|c|}
\hline $\begin{array}{l}\text { Patient } \\
\text { number }\end{array}$ & $\begin{array}{l}\text { Age (years) } \\
\text { Gender (M/F) }\end{array}$ & TNM stage & Histotype & Invasion & $\mathrm{t}($ PAX8-PPAR $\gamma \mathbf{1})$ & $\begin{array}{c}\text { PPAR } \gamma \text { mRNA } \\
(x \text {-fold })\end{array}$ & $\begin{array}{l}\text { PPAR } \gamma \text { protein staining } \\
\text { (\% positive cells/intensity) }\end{array}$ & Follow-up \\
\hline 1 & $50 \mathrm{~F}$ & T2NOMO II & Microfollicular & Widely & Absent & $<3$ & No staining & 3.6 years Alive \\
\hline 2 & $20 \mathrm{~F}$ & T1NOMO I & Macrofollicular & Minimally & Absent & $<3$ & $>80 \% /++++$ & 7 years Alive \\
\hline 3 & $36 \mathrm{~F}$ & T2NOMO I & Macrofollicular & Minimally & Absent & $<3$ & $<20 \% /+$ & 5 years Alive \\
\hline 4 & $63 \mathrm{M}$ & T4N1M1 IVc & Microfollicular & Widely & Absent & $<3$ & $<20 \% /++$ & 3 months Dead \\
\hline 5 & $30 \mathrm{M}$ & T2NOMO I & Microfollicular & Widely & Present & 14.5 & $60-80 \% /+++++$ & 5 years Alive \\
\hline 6 & $52 \mathrm{~F}$ & T1NOMO I & Macrofollicular & Minimally & Absent & $<3$ & $60-80 \% /++$ & 5.5 years Alive \\
\hline 7 & $70 \mathrm{M}$ & T4aNxM1 IVc & Hürtle cell carcinoma & Widely & Absent & $<3$ & $20-40 \% /++$ & 3 years Alive \\
\hline 8 & $59 \mathrm{~F}$ & T4aNOM1 IVc & Insular & Widely & Absent & $<3$ & No staining & 6 months Dead \\
\hline 9 & $51 \mathrm{~F}$ & T3NOMO III & Microfollicular & Widely & Present & 9 & $20-40 \% /++++$ & 4 years Alive \\
\hline 10 & $66 \mathrm{~F}$ & T4aNOMO IVa & Insular & Widely & Absent & $<3$ & $60-80 \% /++$ & 3.5 years Alive \\
\hline 11 & $33 \mathrm{M}$ & T3NOMO I & Macrofollicular & Minimally & Absent & $<3$ & $20-40 \% /+$ & 3.5 years Alive \\
\hline 12 & $51 \mathrm{M}$ & T4aN1aM1 IVc & Insular & Widely & Absent & $<3$ & No staining & 1 year Dead \\
\hline 13 & $65 \mathrm{~F}$ & T2N1aM1 IVc & Insular & Widely & Absent & $<3$ & $<20 \% /+$ & 1.5 years Dead \\
\hline 14 & $32 \mathrm{M}$ & T3N1aM1 II & Microfollicular & Widely & Absent & $<3$ & $<20 \% /+$ & 4 years Alive \\
\hline 15 & $63 \mathrm{M}$ & T3NOMO II & Macrofollicular & Minimally & Absent & $<3$ & $40-60 \% /++$ & 14 years Alive \\
\hline 16 & $52 \mathrm{~F}$ & T3N1M1 IVc & Microfollicular & Widely & Absent & $<3$ & $60-80 \% /+++$ & 4.5 years Dead \\
\hline 17 & $58 \mathrm{M}$ & T3NOMO II & Macrofollicular & Widely & Absent & $<3$ & $20-40 \% /++$ & 9 years Dead \\
\hline 18 & $45 \mathrm{M}$ & T4aN1M1 IVc & Microfollicular & Widely & Absent & $<3$ & $<20 \% /++$ & 6 years Alive \\
\hline 19 & $77 \mathrm{~F}$ & T3N1M1 IVc & Insular & Widely & Absent & $<3$ & No staining & 10 months Dead \\
\hline 20 & $40 \mathrm{~F}$ & T3NOMO I & Microfollicular with papillary structures & Widely & Present & 22 & $60-80 \% /++++$ & 6 years Alive \\
\hline 21 & $37 \mathrm{M}$ & T2NOMO I & Microfollicular & Minimally & Present & 31 & $40-60 \% /+++$ & 3 years Alive \\
\hline \multicolumn{9}{|c|}{ 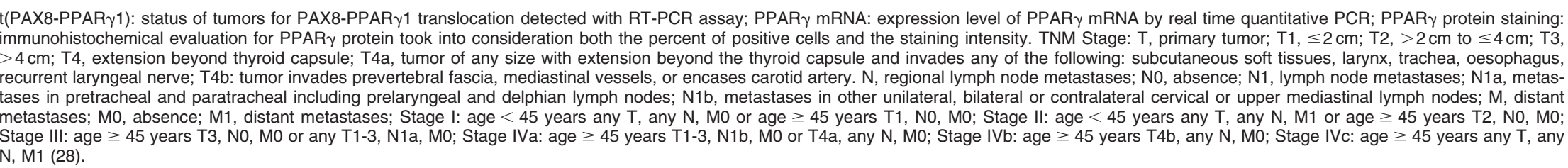 } \\
\hline
\end{tabular}


Table 2 Sequences of primer pairs and TaqMan probes.

\begin{tabular}{|c|c|c|c|}
\hline Gene & Genbank & & Primers and probe \\
\hline \multirow[t]{3}{*}{ PPAR $\gamma 1$} & GI2605496 & Sense & $\begin{array}{l}\text { GCA GGA GCA GAG CAA } \\
\text { AGA GG }\end{array}$ \\
\hline & & Antisense & $\begin{array}{l}\text { CCA GGA ATG CTT TTG } \\
\text { GCA TAC }\end{array}$ \\
\hline & & Probe & $\begin{array}{c}\text { FAM-CCA TCC GCA TCT TTC } \\
\text { A GG GCT GC-TAMRA }\end{array}$ \\
\hline \multirow[t]{3}{*}{ PAX8A } & X69699 & Sense & $\begin{array}{l}\text { CAA CAG CAC CCT GGA } \\
\text { CGA C }\end{array}$ \\
\hline & & Antisense & $\begin{array}{l}\text { AGG GTG AGT GAG GAT } \\
\text { CTG CC }\end{array}$ \\
\hline & & Probe & $\begin{array}{c}\text { FAM-CTG ACC CCT TCC AAC } \\
\text { ACG CCA CTG-TAMRA }\end{array}$ \\
\hline
\end{tabular}

FAM, 6-carboxy-fluorescein; TAMRA, 6-carboxy-tetramethyl-rhodamine.

described (29). In order to exclude potential contamination by the adipose tissue, which also expresses PPAR $\gamma$ transcripts, a leptin Q RT-PCR method was used (30).

\section{Detection of the PPAR $\gamma$ variants}

In order to test whether a particular PPAR $\gamma$ polymorphism is associated with the occurrence of benign or malignant thyroid tumor, DNA from the tumoral tissues was analyzed. Fragments encompassing the two sites of PPAR $\gamma$ polymorphism, namely P12A in the unique PPAR $\gamma 2$ exon and $\mathrm{H} 449 \mathrm{H}$ in the 6 th common exon, were generated from DNA by PCR as previously reported $(31,32)$. The $\mathrm{P} 12 \mathrm{~A}(C \mathrm{CA} \rightarrow \mathrm{GCA})$ polymorphism was analyzed by using BstUI digestion followed by $3 \%$ agarose gel electrophoresis. Two microliters PCR product were digested by $6 \mathrm{U}$ restriction endonuclease BstUI (New England Biolabs, Ozyme, France) at $66^{\circ} \mathrm{C}$ for $1 \mathrm{~h}$. The expected products after digestion with BstUI were $270 \mathrm{bp}$ for normal homozygote, 227 and $43 \mathrm{bp}$ for Pro12Ala homozygote, and 270, 227 and $43 \mathrm{bp}$ for heterozygote. The $\mathrm{H} 449 \mathrm{H}(\mathrm{CAC} \rightarrow \mathrm{CAT})$ polymorphism was detected using PmlI digestion. Two microliters PCR product were digested by $20 \mathrm{U}$ restriction endonuclease PmlI (New England Biolabs) and incubated at $37^{\circ} \mathrm{C}$ overnight followed by a $3 \%$ agarose gel electrophoresis. The expected products were 160 and $107 \mathrm{bp}$ for normal homozygote, 267, 160 and $107 \mathrm{bp}$ for heterozygote and $267 \mathrm{bp}$ for $\mathrm{H} 449 \mathrm{H}$ homozygote.

\section{Immunohistochemistry for PPAR $\gamma$ protein}

Immunohistochemistry was performed on formalinfixed paraffin-embedded $5-\mu \mathrm{m}$ sections of normal, benign and malignant thyroid tissues, with the DAKO LSAB System procedure (DAKO, Carpinteria, CA, USA). Briefly, sections were deparaffinized by serial passages in xylene and in alcohol. After blocking endogenous peroxidase activity, microwave/pressure cooker pretreatment was performed in $1 \mathrm{mM}$ EDTA buffer
$(\mathrm{pH} 8)$. Sections were then incubated for $30 \mathrm{~min}$ at room temperature with a mouse monoclonal antibody anti-PPAR $\gamma$ which recognizes the carboxyl terminus of the protein (Santa Cruz Biotechnology, Santa Cruz, CA, USA). They were washed three times in Tris-HCl $1 \times$ buffer for $5 \mathrm{~min}$ each time and incubated with a peroxidase-conjugated antibody for $15 \mathrm{~min}$ (peroxidase anti-rabbit/mouse DAKO EnVision System cod. K4003). After three further washes, peroxidase staining was revealed in diaminobenzidine tetrahydrochloride (Polysciences Inc., Warrington, PA, USA) with $0.1 \%$ hydrogen peroxide in Tris buffer $0.01 \mathrm{~mol} / \mathrm{l}(\mathrm{pH} 7.2)$. Sections were counterstained with hematoxylin, dehydrated and mounted. Negative controls were obtained by performing the same procedure on tissue sections without the anti-PPAR $\gamma$ antibody incubation step. Immunohistochemical evaluation was assessed by taking into consideration both the percentage of positive cells (noted as percentage of stained cells) and the intensity of staining (noted from + to +++++ ).

\section{Results}

\section{Detection of the PAX8-PPAR $\gamma 1$ rearrangement in human thyroid tissues}

No PAX8-PPAR $\gamma 1$ translocation was detected in normal tissues, hyperfunctioning tissues and in classical papillary carcinomas with characteristic nuclear features. Among the 21 follicular carcinomas analyzed, the presence of the PAX8-PPAR $\gamma 1$ rearrangement was detected in only four samples (19\%) (Fig. 1). Among the 26 hypofunctioning adenomas analyzed, a translocation was also detected in one sample $(4 \%)$. In positive patients, RT-PCR revealed amplification fragments of different sizes. Sequencing of the PCR products from follicular carcinomas showed four transcripts generated by the fusion of different exons of PAX8 (exon 7 , exons 7-8, exons 7-8-9 and exons 7-9) with exon 1 of PPAR $\gamma 1$. Three positive carcinomas were microfollicular carcinomas, two being widely invasive and one minimally invasive (Table 1 ). The remaining one displayed a peculiar histological feature with papillary structures but without the characteristic 'papillary nuclei'. The positive adenoma was an atypical adenoma with a hypercellular and microfollicular pattern, limited by a capsule of variable thickness but without complete invasion. The transcripts were generated by the fusion of exons 7 or 7 and 8 with exon 1 of PPAR $\gamma 1$. All these results were confirmed by an independent PCR based on protocols described by Nikiforova et al. (23) (data not shown).

\section{Determination of PPAR $\gamma$ and PAX8 gene expression in thyroid tissues}

The mRNA levels of the two genes were determined by Q RT-PCR (Fig. 2). PPAR $\gamma$ gene expression was detected 


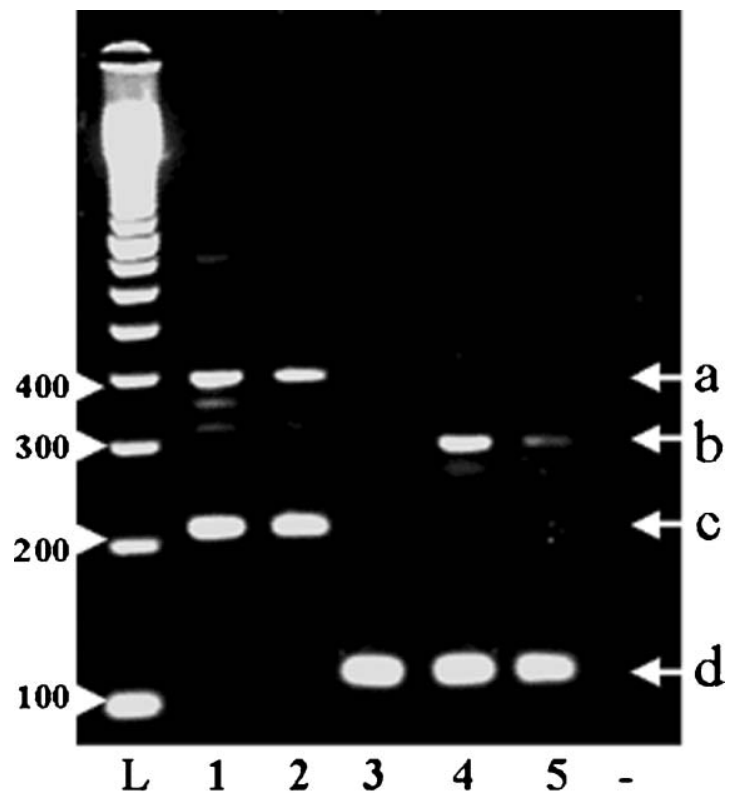

Figure 1 Detection of the PAX8-PPAR 1 translocation by RTPCR in follicular thyroid tumors. Lanes 1 to 4 correspond to follicular thyroid carcinomas and lane 5 corresponds to the follicular thyroid adenoma. RT-PCR revealed amplification fragments of predicted size: (a) 407 bp corresponding to fusion of PAX8 exons 7-8-9 to PPAR 1 exon 1; (b) 305 bp corresponding to fusion of PAX8 exons $7-8$ to PPAR 1 exon 1 ; (c) $217 \mathrm{bp}$ corresponding to fusion of PAX8 exons 7 plus 9 to PPAR 1 exon 1 and (d) $108 \mathrm{bp}$ corresponding to fusion of PAX8 exons $7-8$ and 7 to PPAR $\gamma 1$ exon 1. RT-PCR negative controls are presented in the last lane (-).

in all tissues examined, and its level appeared variable: it was in the normal range in hyperfunctioning tissues and in follicular adenomas without the translocation, whereas it was significantly decreased, by about tenfold, in papillary carcinomas. In contrast, PPAR $\gamma$ mRNA values were in the normal range in follicular carcinomas without the translocation and were increased by 8- to 31-fold in tissues presenting the PAX8PPAR $\gamma 1$ translocation. PAX8A gene expression was similar in normal, hyperfunctioning and hypofunctioning benign thyroid tissues. In contrast, PAX8A gene expression was significantly decreased in papillary and follicular carcinomas, and the transcript levels were decreased to the same extent in samples presenting or not the translocation. Q RT-PCR leptin assay did not show any contamination by adipose tissue (data not shown).

\section{PPAR $\gamma$ polymorphism in benign and malignant thyroid tumors}

There was no association between the PPAR $y$ variant frequencies and the three groups of patients bearing a hypofunctioning adenoma, a papillary carcinoma

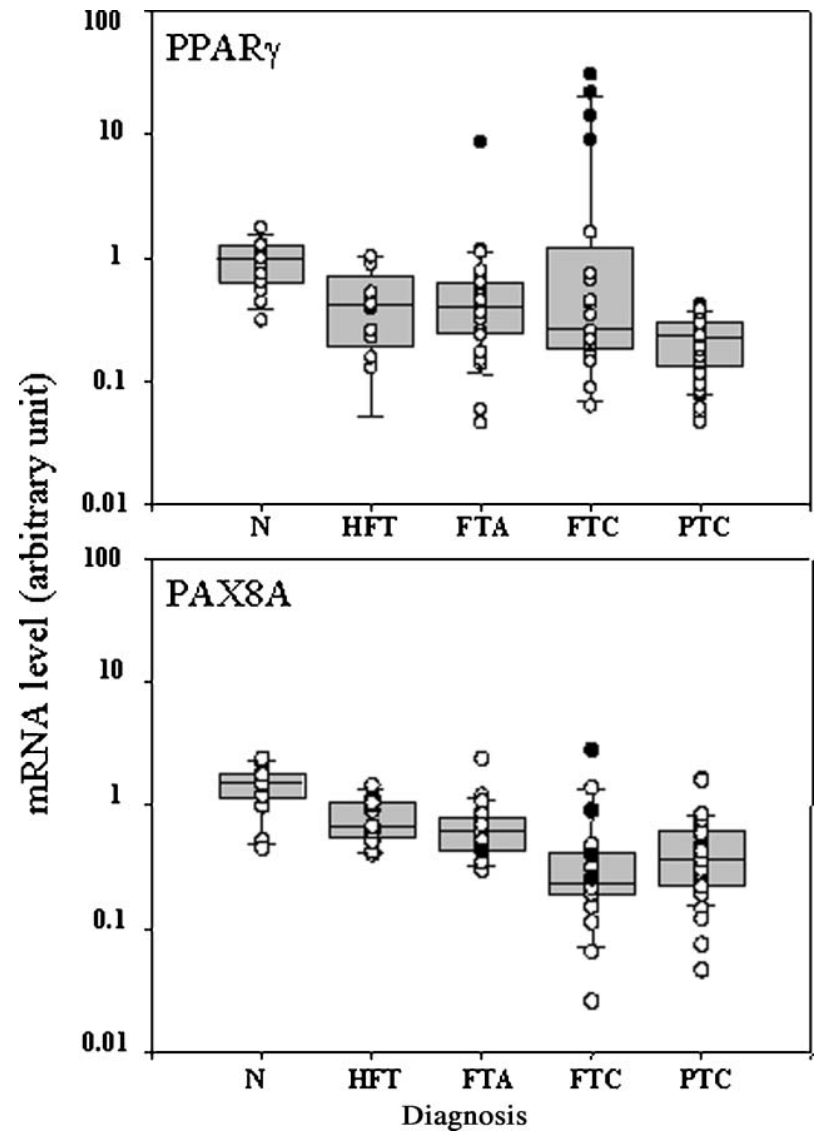

Figure 2 Box plots for PPAR $\gamma$ and PAX8A gene expression levels according to histology (N, normal; HFT, hyperfunctioning tissues; FTA, hypofunctioning follicular thyroid adenomas; FTC, follicular thyroid carcinomas; PTC, papillary thyroid carcinomas). The box shows the limits of the middle half of the data, the line inside the box represents the median. Whiskers are drawn to represent the standard span of the 5th/95th percentile. Solid circles correspond to tumors with PAX8/PPAR $\gamma$ translocation, and open circles correspond to tissue samples without translocation.

or a follicular carcinoma (data not shown). However, the limited size of our series does not permit us to totally rule out the hypothesis that an isoform may predispose to a particular benign or malignant tumor.

\section{PPAR $y$ protein expression in thyroid tissues}

Immunohistochemistry with an antibody directed against the wild-type PPAR $\gamma$ displayed a weak nuclear staining in normal, benign tissues and in papillary carcinomas. In the 17 follicular carcinomas in which no translocation was found, nuclear staining was absent in four samples, was weakly positive in eight samples (intensity: + to ++ , in $20-40 \%$ of cancer cells) and was diffusely positive and intense in five samples (intensity: +++ to +++++ , in $40-60 \%$ of cancer cells). In the four follicular carcinomas and in the hypofunctioning follicular adenoma with the PAX8-PPAR $y 1$ 
translocation, a strong nuclear staining (intensity: +++ to +++++ ) was observed in $40-80 \%$ of tumor cells (Fig. 3).

\section{Correlation with clinical features}

No relationship was found between the presence of the PAX8-PPAR $\gamma 1$ rearrangement and the clinical status of the patients, including the age, the TNM stage, the ${ }^{131} \mathrm{I}$ uptake and the outcome (Table 1).

\section{Discussion}

In the present report, the status of both PAX8 and PPAR $y 1$ gene expression was examined in a large series of normal, benign and malignant thyroid tissues by means of a rapid and semi-automated real-time $Q$ RT-PCR method. Both types of transcripts were detected in all normal thyroid tissues examined.

Analysis was first focused on follicular carcinomas because the PAX8-PPAR $\gamma 1$ rearrangement had
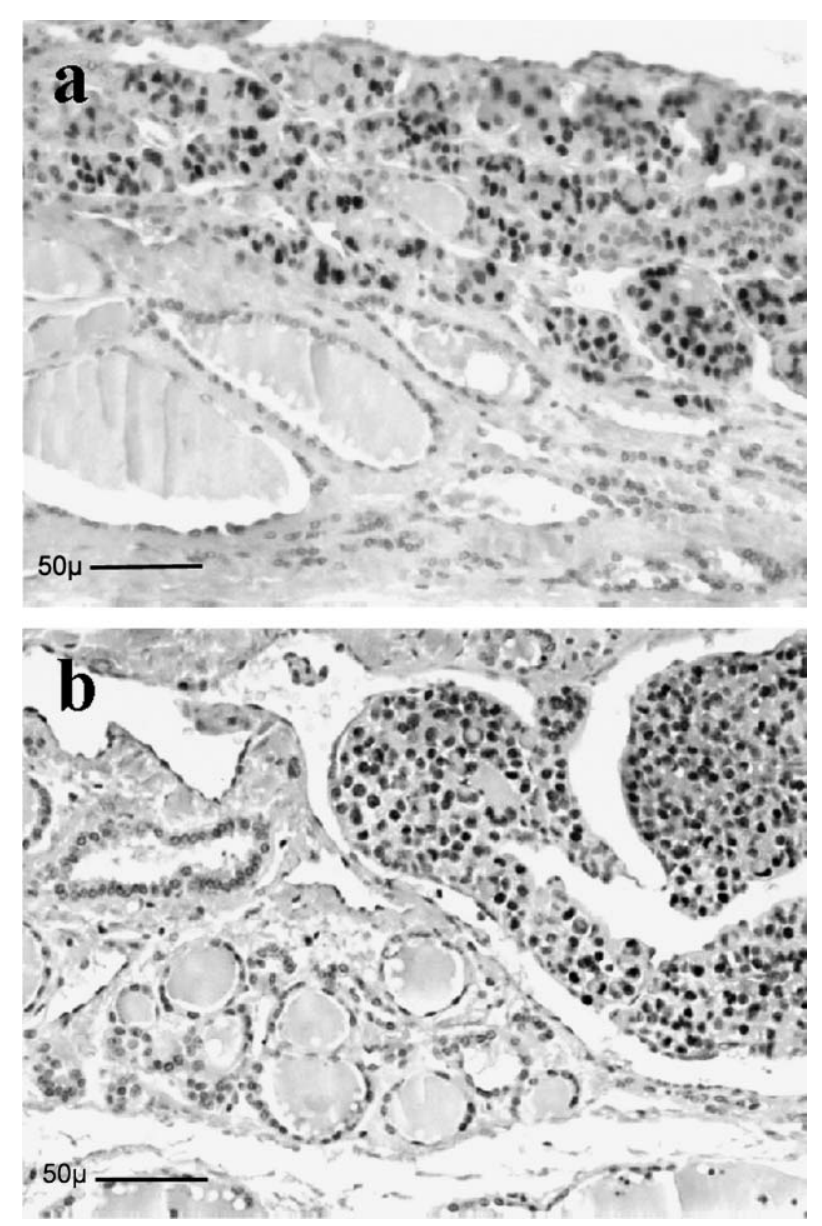

Figure 3 PPAR $\gamma$ immunostaining in two follicular thyroid carcinomas ( $a$ and $b$ ). A large majority of tumor cells (upper right) displays a strong nuclear staining whereas the normal counterpart (lower left) is not or is weaky stained (magnification $\times 250$ ). Scale bar indicates $50 \mu \mathrm{m}$. previously been implicated in their pathogenesis (7). Using a conventional RT-PCR method followed by sequencing of amplified products, $19 \%$ of the follicular carcinoma samples presented the PAX8-PPAR $\gamma 1$ rearrangement. This is in ageement with other studies showing that the frequency of the translocation is lower than initially reported $(20-24)$. We also found the translocation in one of the 26 hypofunctioning adenomas studied. This is also in agreement with previous studies in which the translocation was found in a low percentage of atypical adenomas. Indeed, this atypical adenoma, like the positive adenomas in the previous series may in fact be a minimally invasive follicular carcinoma treated at an early stage. Thus, our results also confirm the specificity of the PAX8-PPAR $\gamma 1$ rearrangement for the follicular histotype of thyroid tumors and its absence in papillary carcinomas. However, the rearrangement was found in both minimally and widely invasive follicular cancers.

It has been suggested that immunohistochemistry could be a sensitive, specific and rapid tool for the detection of this translocation (7). In fact, the anti-PPAR $\gamma$ antibody provided a strong nuclear staining in all tumors presenting the PAX8-PPAR $\gamma 1$ rearrangement. However, staining was strong also in some samples in which no translocation was found and was detected in the majority of follicular carcinoma cells, corresponding to the expression of either the wild-type PPAR $\gamma$ protein or to a rearrangement with another fusion gene (27). Therefore, due to its lack of specificity, this method cannot be used alone for the detection of the PAX8-PPAR $\gamma 1$ translocation (26). Although the experimental design of our Q RT-PCR method did not allow us to distinguish between wild-type PPAR $\gamma$ and fusion oncogene transcripts, our analysis clearly demonstrates that high levels of PPAR $\gamma$ transcripts were found only in the follicular tumors presenting the PAX8-PPAR $\gamma 1$ rearrangement as detected by RT-PCR and in which a strong immunostaining was also observed. This observation suggests that PPAR $\gamma$ Q RT-PCR could be a convenient method for detecting the PAX8-PPAR $\gamma 1$ rearrangement. Interestingly, PAX8 gene expression was not different in thyroid tissues either positive or negative for the presence of the translocation. This might be explained by the strong expression of PAX8 in thyroid tissue, as compared with a weak PPAR $\gamma$ expression, that acts as a promoter of the expression of the chimeric gene.

The level of PPAR $\gamma$ transcripts was significantly lower in papillary carcinomas than in benign adenomas and follicular carcinomas. Using a semi-quantitative RT-PCR and immunohistochemistry, Aldred et al. (24) also detected a down-regulation of PPAR $\gamma$ gene expression in all tumors tested, including follicular carcinomas. Reports on PPAR $\gamma$ gene expression in thyroid tumoral cell lines are contradictory, with either an upregulation (11) or a down-regulation (12). Altogether, the relevance of these observations remains to be 
investigated, as it would be of interest to determine whether two different processes, a decrease in gene expression in papillary carcinomas and a dominant negative suppressor effect in follicular carcinomas bearing the PAX8-PPAR $\gamma 1$ rearrangement, contribute or not to the same action on the oncogenic process.

\section{Acknowledgements}

The authors thank Dr I Biéche and Prof. M Vidaud (Faculté des Sciences Pharmaceutiques and Biologiques, Université René-Descartes, Paris) for helpful advice and for the development of the leptin $Q$ RT-PCR assay, and Dr N Bellon (Institut GustaveRoussy) for statistical analysis. This work was supported by grants from Electricité de France, CEA LRC29V and Association pour la Recherche sur le Cancer. $\mathrm{C} \mathrm{M}$ is a recipient of a grant from the Société Française du Cancer.

\section{References}

1 Hedinger C, Williams ED \& Sobin LH. Histological typing of thyroid tumors. In International Histological Classification of Tumors, 2nd edition, vol. 11. Berlin: Springer-Verlag, 1998.

2 Fagin FA. Molecular genetics of tumors of thyroid follicular cells. In The Thyroid, 8th edition, pp 886-898. Eds LE Braverman \& RD Utiger. Philadelphia: Lippincott, Williams and Wilkins, 2000.

3 Pierotti MA. Chromosomal rearrangements in thyroid carcinomas: a recombination or death dilemma. Cancer Letters 2001 $1661-7$

4 Bongarzone I, Butti MG, Coronelli S, Borrello MG, Santoro M, Mondellini P, Pilotti S, Fusco A, Della Porta G \& Pierotti MA. Frequent activation of ret protooncogene by fusion with a new activating gene in papillary thyroid carcinomas. Cancer Research 1994 $542979-2985$.

5 Roque L, Rodrigues R, Pinto A, Moura-Nunes V \& Soares J. Chromosome imbalances in thyroid follicular neoplasms: a comparison between follicular adenomas and carcinomas. Genes Chromosomes and Cancer $200336292-302$.

6 Lui W, Kytölä S, Anfalk L, Larsson C \& Farnebo L. Balanced translocation (3;7) (p25;q34): another mechanism of tumorigenesis in follicular thyroid carcinomas? Cancer Genetics and Cytogenetics $2000119109-112$.

7 Kroll TG, Sarraf P, Pecciarini L, Chen C, Mueller E, Spiegelman BM \& Fletcher J. PAX8-PPAR $\gamma 1$ fusion oncogene in human thyroid carcinoma. Science 2000289 1357-1360.

8 Desvergne B \& Wahli W. Peroxisome proliferator-actived receptors: nuclear control of metabolism. Endocrine Review 199920 649-688.

9 Rosen ED \& Spiegelman BM. PPAR gamma: a nuclear regulator of metabolism, differentiation, and cell growth. Journal of Biological Chemistry $200127637731-37734$.

10 Koeffler HP. Peroxisome proliferator-activated receptor gamma and cancers. Clinical Cancer Research 20039 1-9.

11 Ohta K, Endo T, Haraguchi K, Hershman JM \& Onaya T. Ligands for peroxisome proliferator-activated receptor gamma inhibit growth and induce apoptosis of human papillary thyroid carcinoma cells. Journal of Clinical Endocrinology and Metabolism $2001862170-2177$.

12 Martelli ML, Iuliano R, Le Pera I, Sama I, Monaco C, Cammarota S, Kroll T, Chiariotti L, Santoro M \& Fusco A. Inhibitory effects of peroxisome proliferator-activated receptor gamma on thyroid carcinoma cell growth. Journal of Clinical Endocrinology and Metabolism $2002 \mathbf{8 7} 4728-4735$.
13 Chung SH, Onoda N, Ishikawa T, Ogisawa K, Takenaka C, Yano Y, Hato F \& Hirakawa K. Peroxisome proliferator-activated receptor gamma activation induces cell cycle arrest via the p53-independent pathway in human anaplastic thyroid cancer cells. Japanese Journal of Cancer Research 200293 1358-1365.

14 Ikezoe T, Miller CW, Kawano S, Heaney A, Williamson EA, Hisatake J, Green E, Hofmann W, Taguchi H \& Koeffler HP. Mutational analysis of the peroxisome proliferator-activated receptor gamma gene in human malignancies. Cancer Research 200161 5307-5310.

15 Smith WM, Zhou XP, Kurose K, Gao X, Latif F, Kroll T, Sugano K, Cannistra SA, Clinton SK, Maher ER, Prior TW \& Eng C. Opposite association of two PPARgamma variants with cancer: overrepresentation of $\mathrm{H} 449 \mathrm{H}$ in endometrial carcinoma cases and underrepresentation of $\mathrm{P} 12 \mathrm{~A}$ in renal cell carcinoma cases. Human Genetics 2001109 146-151.

16 Yoshimura R, Matsuyama M, Segawa Y, Hase T, Mitsuhashi M, Tsuchida K, Wada S, Kawahito Y, Sano H \& Nakatani T. Expression of peroxisome proliferator-activated receptors (PPARs) in human urinary bladder carcinoma and growth inhibition by its agonists. International Journal of Cancer $2003 \mathbf{1 0 4}$ 597-602.

17 Damante G, Tell G \& Di Lauro R. A unique combination of transcription factors controls differentiation of thyroid cells. Progress in Nucleic Acid Research and Molecular Biology $200066307-356$.

18 Fabbro D, Di Loreto C, Beltrami CA, Belfiore A, Di Lauro R \& Damante G. Expression of thyroid-specific transcription factors TTF-1 and PAX-8 in human thyroid neoplasms. Cancer Research $1994544744-4749$.

19 Nikiforova MN, Biddinger PW, Caudill CM, Kroll TG \& Nikiforov YE. PAX8-PPARgamma rearrangement in thyroid tumors: RT-PCR and immunohistochemical analyses. American Journal of Surgical Pathology $2002261016-1023$.

20 Marques AR, Espadinha C, Catarino AL, Moniz S, Pereira T, Sobrinho LG \& Leite V. Expression of PAX8-PPAR gamma 1 rearrangements in both follicular thyroid carcinomas and adenomas. Journal of Clinical Endocrinology and Metabolism 200287 3947-3952.

21 Cheung L, Messina M, Gill A, Clarkson A, Learoyd D, Delbridge L, Wentworth J, Philips J, Clifton-Bligh R \& Robinson BG. Detection of the PAX8-PPAR gamma fusion oncogene in both follicular thyroid carcinomas and adenomas. Journal of Clinical Endocrinology and Metabolism $2003 \mathbf{8 8} 354-357$.

22 French CA, Alexander EK, Cibas ES, Nose V, Laguette J, Faquin W, Garber J, Moore F Jr, Fletcher JA, Larsen PR \& Kroll TG. Genetic and biological subgroups of low-stage follicular thyroid cancer. American Journal of Pathology 2003162 1053-1060.

23 Nikiforova MN, Lynch RA, Biddinger PW, Alexander EK, Dorn GW 2nd, Tallini G, Kroll TG \& Nikiforov YE. RAS point mutations and PAX8-PPAR gamma rearrangement in thyroid tumors: evidence for distinct molecular pathways in thyroid follicular carcinoma. Journal of Clinical Endocrinology and Metabolism $2003 \mathbf{8 8}$ 2318-2326.

24 Aldred MA, Morrison C, Gimm O, Hoang-Vu C, Krause U, Dralle H, Jhiang $\mathrm{S} \&$ Eng C. Peroxisome proliferator-activated receptor gamma is frequently downregulated in a diversity of sporadic nonmedullary thyroid carcinomas. Oncogene $2003 \mathbf{2 2}$ $3412-3416$.

25 Zhu Z, Gandhi M, Nikiforova MN, Fischer AH \& Nikiforov YE. Molecular profile and clinical-pathologic features of the follicular variant of papillary thyroid carcinoma. An unusually high prevalence of ras mutations. American Journal of Clinical Pathology 2003 $12071-77$.

26 Gustafson KS, LiVolsi VA, Furth EE, Pasha TL, Putt ME \& Baloch ZW. Peroxisome proliferator-activated receptor gamma expression in follicular-patterned thyroid lesions. Caveats for the use of immunohistochemical studies. American Journal of Clinical Pathology 2003120 175-181.

27 Dwight T, Thoppe SR, Foukakis T, Lui WO, Wallin G, Hoog A, Frisk T, Larsson C \& Zedenius J. Involvement of the PAX8/peroxisome 
proliferator-activated receptor gamma rearrangement in follicular thyroid tumors. Journal of Clinical Endocrinology and Metabolism $2003884440-4445$.

28 American Joint Committee on Cancer, Thyroid. In AJCC Cancer Staging Handbook, 6th edition, ch. 8, pp 89-98. New York: Springer, 2002.

29 Lazar V, Bidart JM, Caillou B, Mahé C, Lacroix L, Filetti S \& Schlumberger M. Expression of the $\mathrm{Na}^{+} / \mathrm{I}^{-}$symporter gene in human thyroid tumors: a comparison study with other thyroidspecific genes. Journal of Clinical Endocrinology and Metabolism $1999843228-3234$

30 Bieche I, Franc B, Vidaud D, Vidaud M \& Lidereau R. Analyses of MYC, ERBB2, and CCND1 genes in benign and malignant thyroid follicular cell tumors by real-time polymerase chain reaction. Thyroid 200111 147-152.
31 Valve R, Sivenius K, Miettinen R, Pihlajamaki J, Rissanen A, Deeb SS, Auwerx J, Uusitupa M \& Laakso M. Two polymorphisms in the peroxisome proliferator-activated receptor-gamma gene are associated with severe overweight among obese women. Journal of Clinical Endocrinology and Metabolism $1999843708-3712$.

32 Yen CJ, Beamer BA, Negri C, Silver K, Brown KA, Yarnall DP, Burns DK, Roth J \& Shuldiner AR. Molecular scanning of the human peroxisome proliferator activated receptor gamma (hPPAR gamma) gene in diabetic Caucasians: identification of a Pro12Ala PPAR gamma 2 missense mutation. Biochemical and Biophysical Research Communications 1997241 270-274.

Received 27 February 2004

Accepted 22 April 2004 